\title{
Why we fail: mechanisms and co-factors of unsuccessful thrombectomy in acute ischemic stroke
}

\author{
Dominik M. Heider ${ }^{1}$ (D) Andreas Simgen ${ }^{1} \cdot$ Gudrun Wagenpfeil $^{2} \cdot$ Philipp Dietrich $^{1} \cdot$ Umut Yilmaz $^{1}$. \\ Ruben Mühl-Benninghaus ${ }^{1}$. Safwan Roumia ${ }^{1} \cdot$ Klaus Faßbender $^{3} \cdot$ Wolfgang Reith $^{1} \cdot$ Michael Kettner $^{1}$
}

Received: 22 August 2019 / Accepted: 7 January 2020 / Published online: 23 January 2020

(C) The Author(s) 2020

\begin{abstract}
Purpose Mechanical thrombectomy (MT) is an effective treatment for patients suffering from acute ischemic stroke. However, recanalization fails in about $16.5 \%$ of interventions. We report our experience with unsuccessful MT and analyze technical reasons plus patient-related parameters for failure.

Methods Five hundred ninety-six patients with acute ischemic stroke in the anterior circulation and intention to perform MT with an aspiration catheter and/or stent retriever were analyzed. Failure was defined as 0,1 , or $2 \mathrm{a}$ on the mTICI scale. Patients with failing MT were analyzed for interventional progress and compared to patients with successful intervention, whereby parameters included demographics, medical history, stroke presentation, and treatment.

Results One hundred of the 596 (16.8\%) interventions failed. In 20 cases, thrombus could not be accessed or passed with the device. Peripheral arterial occlusive disease is common in those patients. In 80 patients, true stent retriever failure occurred. In this group, coagulation disorders are associated with poor results, whereas atrial fibrillation is associated with success.

The administration of intravenous thrombolysis and intake of nitric oxide donors are associated with recanalization success. Intervention duration was significantly longer in the failing group.

Conclusion In $20 \%$ of failing MT, thrombus cannot be reached/passed. Direct carotid puncture or surgical arterial access could be considered in these cases.

In $80 \%$ of failing interventions, thrombus can be passed with the device, but the occluded vessel cannot be recanalized. Rescue techniques can be an option. Development of new devices and techniques is necessary to improve recanalization rates. Assessment of pre-existing illness could sensitize for occurring complications.
\end{abstract}

Keywords Stent retriever failure $\cdot$ Unsuccessful thrombectomy $\cdot$ Stroke $\cdot$ Intraarterial treatment $\cdot$ Interventional thrombolysis

\section{Introduction}

\section{Background}

Mechanical thrombectomy (MT) is a therapeutic option for patients with acute ischemic stroke; it became more important in recent years

Dominik M. Heider

1 Department of Diagnostic and Interventional Neuroradiology, Saarland University Hospital, 66421 Homburg/Saar, Germany

2 Institute of Medical Biometry, Epidemiology and Medical Informatics, Saarland University, Medical Faculty, Homburg/ Saar 66421, Germany

3 Department of Neurology, Saarland University Hospital, 66421 Homburg/Saar, Germany due to several randomized controlled trials proving better therapeutic outcome compared to intravenous tissue-type plasminogen activator for intravenous thrombolysis (IVT) alone [1-5].

Literature reports success rates of about $83 \%$, whereas $17 \%$ of the interventions are not successful [6]. We report our experience with unsuccessful endovascular treatment and analyze technical reasons for failure as well as patient-related parameters, especially medical history.

In our retrospective single-center study, we investigated all treatment protocols of failing interventions and screened those patients for associated pre-existing illness and medication. There are many possible reasons for failure, from unsuccessful vascular access to distal embolization, which are described in recent literature $[7,8]$.

Elevation of recanalization rates is an important step for improved stroke therapy and better patient outcome $[9,10]$. 


\section{Material and methods}

\section{Methods and study design}

In a retrospective single-center study, 596 patients with acute ischemic stroke of the anterior circulation (internal carotid artery, middle cerebral artery) were analyzed; they underwent MT with an aspiration catheter and/or stent retriever systems at the neurovascular center of a German university hospital from January 2014 to October 2018. At our center, MT is delivered $24 / 7$ by 5 experienced neurointerventionalists. The study included all patients with intention to perform interventional thrombolysis in order to analyze any occurring circumstances leading to unsuccessful recanalization.

In our study, failure was defined as 0,1 , or $2 \mathrm{a}$ on the mTICI scale. The mTICI scale is a well investigated angiographic score for measuring recanalization success [11]. Figure 1 provides an overview of the selection process.

First, treatment protocols of unsuccessful MTs were investigated to find out the specific reasons of failure. Next, they were analyzed for interventional progress in order to identify the exact step when MT had failed.

Patients were analyzed for demographics, medical history including long-term medication, localization of the occlusion, severity of symptoms measured by the NIHSS [12], initial blood laboratory, and acute therapy. In addition, elapsed time from symptom onset to IVT and to interventional treatment were recorded, as well as intervention duration.

Additionally, patients with unsuccessful recanalization are divided into two subgroups, as indicated in Fig. 1.
Group A: Patients with technical-mechanical reasons for failure (occlusion site cannot be passed with device). Group B: Patients with other reasons for failure (occlusion site can be passed but vessel cannot be completely recanalized).

The failing group in total and the two subgroups A and B were compared to a randomly selected group of 100 patients who underwent successful MT (mTICI 2b, 2c, and 3) in the same period at our center.

Data was recorded from treatment protocols, the angiographic system, and medical reports at discharge. Clinical data, especially examination results at discharge or later, was not collected at any time, since our study focused on angiographic parameters.

\section{Statistics}

Absolute and relative frequencies are given for categorical data, median and IQR, or mean and SD for metric variables, as indicated. Comparisons of the group of successful interventions with the group of failing interventions and subgroups A and B were made using the Wilcoxon Mann-Whitney $U$ test for quantitative variables and with the Fisher's exact test and $X_{2}$ test for qualitative variables, as appropriate. Significant lever was set at $5 \%$, with a $p$ value $\leq 0.05$ considered as significant.

Statistical analysis was performed with SPSS, Version 25.0 (IBM Corporation, Armonk, New York, USA).
Fig. 1 Selection process and subgroups' definition

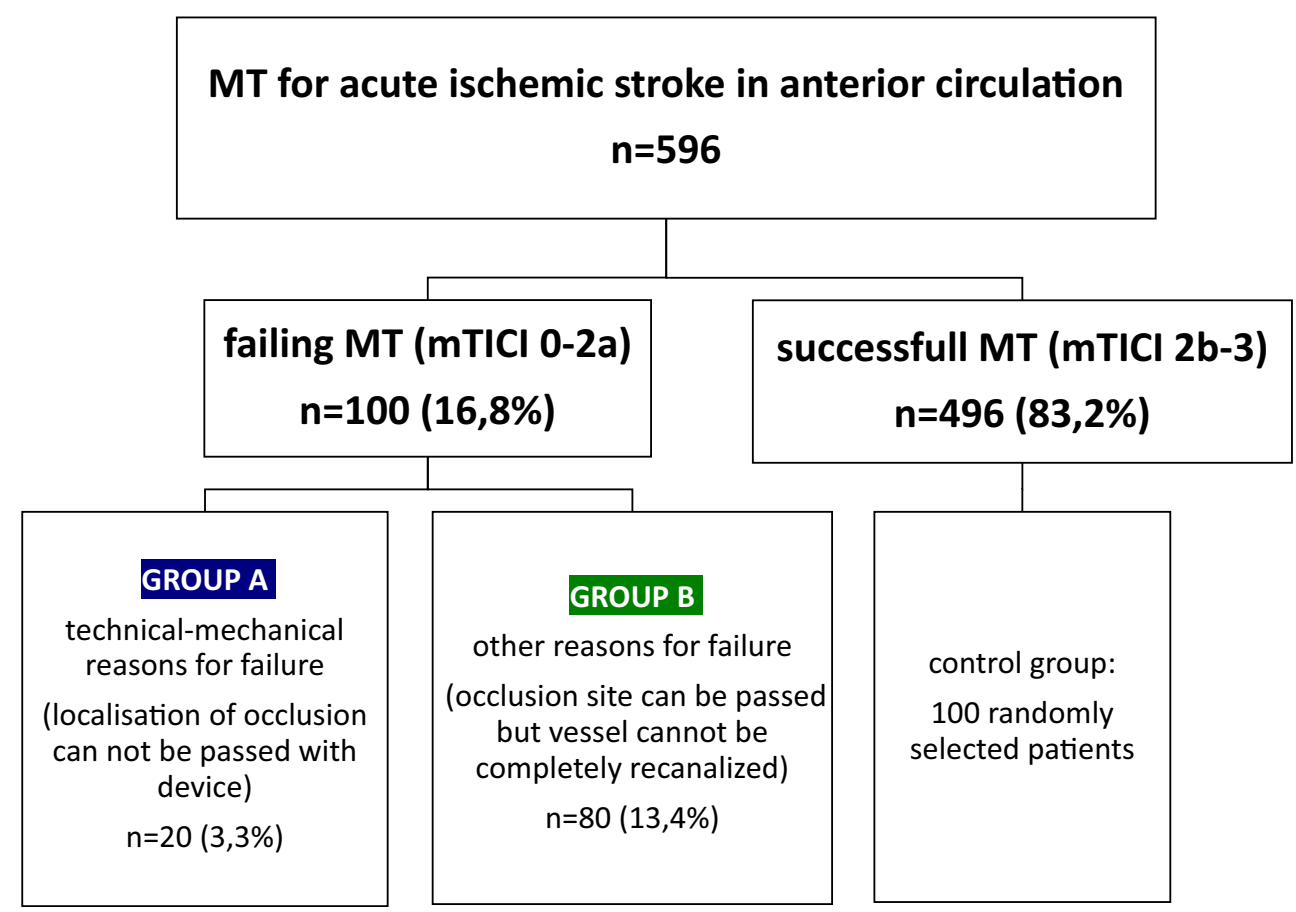




\section{Intervention procedure}

MT was performed immediately after CT and CT angiography imaging under the following conditions: (1) acute ischemic stroke with NIHSS $>3$ or severe isolated neurological deficit (aphasia, hemianopsia, isolated paresis of one limb), (2) large vessel occlusion with corresponding neurological deficits, (3) exclusion of hemorrhage, and (4) absence of any other individual contraindications for thrombectomy.

All the interventions were performed under general anesthesia and endotracheal intubation on a biplane angiography unit (Siemens Axiom Artis, Siemens Healthcare, Erlangen, Germany). The institution standard for occlusion of the anterior circulation consists of femoral approach with a $6 \mathrm{~F}$ sheath (Cook Group Inc., Bloomington, Indiana, USA), which is placed as distal as possible in the internal carotid artery. Radial vessel access is very rare (1 of 100 in the failing group), and direct carotid puncture is currently not performed at our center. After microwire-assisted placement of the microcatheter, the microwire was exchanged for a thrombectomy device, and a stent retriever was deployed in the occluded vessel distal of the target lesion. Stent-retriever thrombectomy was executed with manual aspiration. If the intervention failed, another run was performed and/or material was changed. The mean number of maneuvers in total was $2.9 \pm 2.0$ (mean $\pm \mathrm{SD}$ ), maximum 9 .

In some cases, especially proximal occlusions of large vessels, aspiration-first thrombectomy was carried out, while in other cases, a microcatheter was not used due to access difficulties. The choice of method and materials was made by the neurointerventionalist as well as the decision to terminate the procedure and to perform a rescue technique as permanent stenting or intraarterial tissue plasminogen activator. At the end of the intervention, post-interventional, the mTICI scale score was recorded.

\section{Results}

Between January 2014 and October 2018, 100 of the 596 (16.8\%) interventions failed according to our definition: 49 patients had a post-interventional mTICI scale score of 0,18 had an mTICI scale score of 1 , and 33 had an mTICI scale score of 2a. Table 1 gives an overview of failing interventions during the years 2014 until 2018.

\section{Demographic data}

As shown in Table 2, there was no significant difference in age or sex. The median age was $73.4 \pm 12.8$ years in the successful group and $71.1 \pm 12.9$ in the failing group. In subgroup $B$, patients seem to be slightly younger $(70.1 \pm 13.3$ years), without the difference being significant. A small female predominance $(n=60 ; 60.0 \%)$ can be observed in the successful group, while all the other groups are almost equal in sex distribution (45.0-55.0\%).
Table 1 Failing interventions from 2014 until 2018 by years

Number of mTICI 0 mTICI 1 mTICI 2a \% failing interventions

\begin{tabular}{lrrrrr}
\hline 2014 & 84 & 7 & 4 & 3 & $16.7 \%$ \\
2015 & 102 & 8 & 6 & 12 & $25.4 \%$ \\
2016 & 135 & 13 & 2 & 9 & $17.8 \%$ \\
2017 & 141 & 10 & 3 & 5 & $12.8 \%$ \\
$01-10 / 2018$ & 134 & 11 & 3 & 4 & $13.4 \%$ \\
$2014-2018$ & 596 & 49 & 18 & 33 & $16.8 \%$ \\
\hline
\end{tabular}

\section{Interventional progress and material}

Intervention was divided into 6 steps, as shown in Fig. 2.

In 20 of the 100 patients, it was not possible to reach and/or pass the occlusive lesion (steps 1-3 in Fig. 2, technicalmechanical reasons for failure). Most of them had elongation $(9 / 20,45.0 \%)$ or stenosis $(6 / 20 ; 30.0 \%)$, which could not be passed with the endovascular device. In 2 cases (10.0\%), femoral puncture was not possible, and in 1 case $(5.0 \%)$, a carotid dissection was the reason for stroke symptoms. Thrombus passage with a microcatheter or microwire was not possible in 2 cases (10.0\%). These 20 patients form group A, following the subgroups' definition above.

In 80 of the 100 patients, the occluded site could be reached and/or passed, but the vessel could not be recanalized successfully (steps $4-6$ in Fig. 2, true stent retriever failure). Those 80 patients form group B for the subgroup analysis. In most cases, peripheral ramifications remained occluded after the intervention $(40 / 80$, $50.0 \%)$ or no clot material could be removed at all $(25 / 80$, $31.3 \%)$. Ten patients suffered from a re-occlusion, $6(7.5 \%)$ at the same site and $4(5.0 \%)$ more proximal at a stent in the carotid artery that was placed due to a tandem lesion. Subarachnoid hemorrhage $(3 / 80,3.8 \%)$ and iatrogenic dissection $(1 / 80,1.3 \%)$ leading to premature termination are rare. In 1 case $(1.3 \%)$, intervention was terminated for a high-risk profile (distal occlusion and difficult vascular anatomy with high risk of vessel perforation).

During the study period from January 2014 to October 2018, several types of stent retrievers and catheter systems were used in the group of failing interventions: 104 stent retrievers, including 60 Solitaires (Covidien, Mansfield, Massachusetts, USA), 15 ERICs (MicroVention, Tustin, California, USA), 16 embo-trap (Neuravi, Galway, Ireland), 12 pRESET (Phenox, Bochum, Germany), and 1 TREVO (Stryker, Kalamazoo, Michigan, USA). Furthermore, 92 intermediate catheters were used: 57 Sofia Intermediate Catheters (MicroVention, Tustin, CA, USA), 32 ACE or MAX Reperfusion Catheters (Penumbra, Alameda, CA, USA), 1 Neurobridge Intermediate Catheter (Acandis, Pforzheim, Germany), and 1 Envoy Guiding Catheter (DePuy Synthes Codman Neuro, Raynham, MA, USA).

Evaluation of the 100 failing interventions produces the following results: In 21 cases, no maneuver at all was possible, 
Table 2 Demographic parameters

\begin{tabular}{llllllll}
\hline & $\begin{array}{l}\text { Success } \\
n=100\end{array}$ & $\begin{array}{l}\text { Failure } \\
n=100\end{array}$ & $p$ & $\begin{array}{l}\text { Group A } \\
n=20\end{array}$ & $\begin{array}{l}\text { Group B } \\
n=80\end{array}$ & $p$ \\
\hline Sex & & & & & & & \\
Female (\%) & $60(60.0)$ & $47(47.0)$ & $0.089^{\mathrm{A}}$ & $9(45.0)$ & $0.227^{\mathrm{A}}$ & $38(47.5)$ & $0.100^{\mathrm{A}}$ \\
Male (\%) & $40(40.0)$ & $53(53.0)$ & $0.089^{\mathrm{A}}$ & $11(55.0)$ & $0.227^{\mathrm{A}}$ & $42(52.5)$ & $0.100^{\mathrm{A}}$ \\
$\begin{array}{c}\text { Age [years] } \\
(X \pm \text { SD) }\end{array}$ & $73.4 \pm 12.8$ & $71.1 \pm 12.9$ & $0.132^{\mathrm{B}}$ & $74.9 \pm 10.8$ & $0.972^{\mathrm{B}}$ & $70.1 \pm 13.3$ & $0.078^{\mathrm{B}}$ \\
\hline
\end{tabular}

$A$, Fisher's exact test; $B$, Mann-Whitney $U$ test; $\bar{X}$, mean; $S D$, standard deviation for example, due to access problems. In 7 , a stent retrieveralone maneuver and in 6 cases an aspiration-alone maneuver was performed, while in the 66 remaining cases, a combination of aspiration and stent retriever withdrawal was conducted. In 9 cases, an aspiration catheter was changed during the intervention; in 29 cases, a change of stent retriever was conducted, and in one case, a stent retriever was changed twice.

In 19 patients, balloon angioplasty was performed during the intervention; in 14, a stent was implanted.

\section{Comparisons of medical history include long-term medication, localization of the occlusion, severity of symptoms, initial blood laboratory, and acute therapy}

All the characteristics of failing and successful intervention groups are given in Table 3 .

In our study, IVT before intervention is associated with recanalization success. In the successful group (SG), $51.5 \%$ of all patients were treated with intravenous tissue plasminogen activator, while in the failure group (FG), only $35.0 \%$ received this medication $(p=0.032)$. Furthermore, there was a statistical correlation between the long-term intake of nitrates and a successful intervention $(\mathrm{SG}=8.0 \%$ vs. $\mathrm{FG}=$ $1.0 \% ; p=0.035)$.

Intervention duration was significant longer in failing interventions $(\mathrm{SG}=23$ (14-36) $\mathrm{min}$ vs. $\mathrm{FG}=50(36-90) \mathrm{min} ; p=0.000)$.

Regarding coagulation therapy with coumarins or direct oral anticoagulants, no significant difference was found in any of the groups. Time factors related to symptom onset, to IVT, and to intervention do not seem to play a role in the success of recanalization. Laboratory parameters for inflammatory response and coagulation were comparable in all groups (see Table 2).

\section{Subgroup analysis}

In addition to the results given for the total failing group, there are interesting findings for the two subgroups:

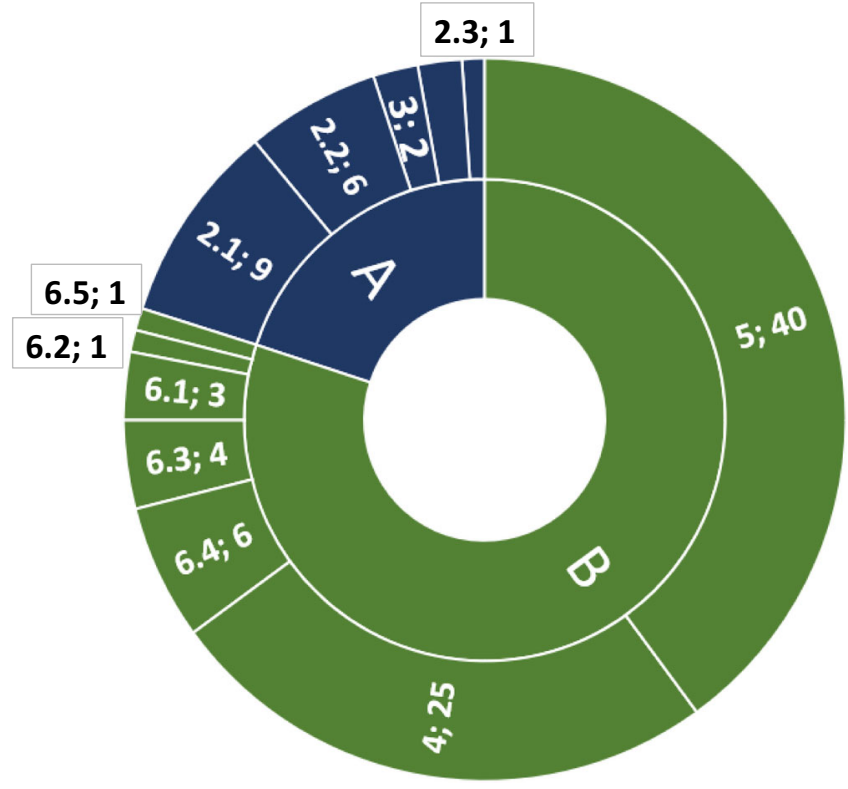

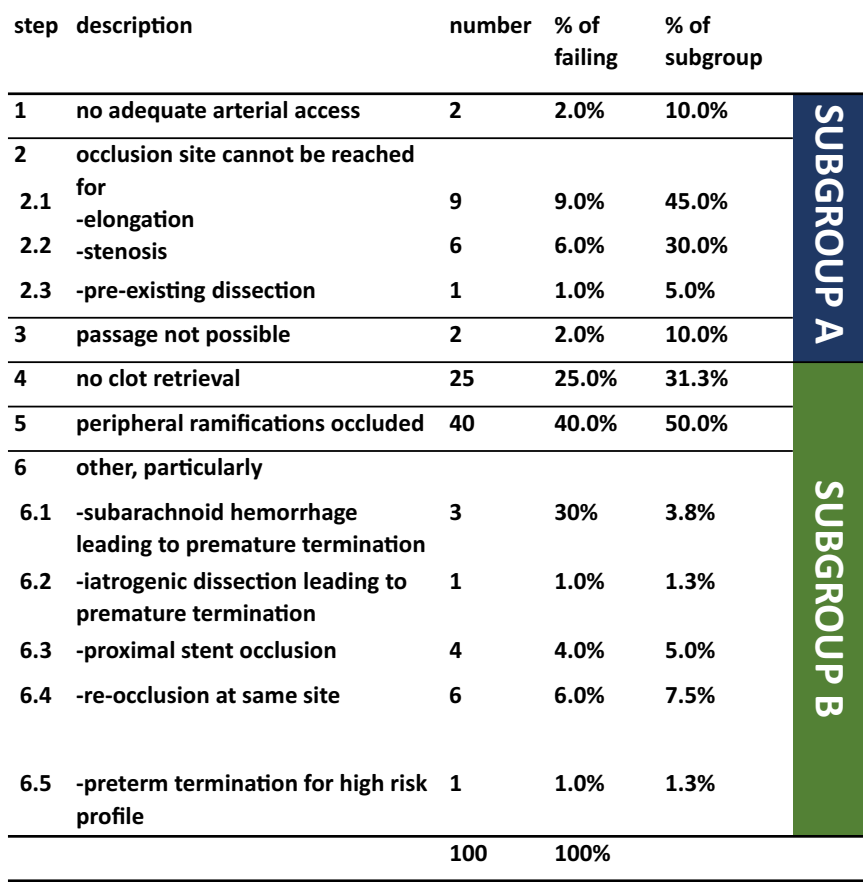

Step and proportion of all failing interventions are given in the labeling, e.g. "2.1; 9": $9 \%$ of all failing interventions failed in step 2.1 .

Fig. 2 Sunburst diagram for interventional progress 
Table 3 Patient-related parameters ( $p$ values are given for a comparison of the group of failing interventions with the successful group and for a comparison of subgroups A and B with the successful group)

\begin{tabular}{|c|c|c|c|c|c|c|c|}
\hline & $\begin{array}{l}\text { Success } \\
n=100\end{array}$ & $\begin{array}{l}\text { Failure } \\
n=100\end{array}$ & $p$ & $\begin{array}{l}\text { Group A } \\
n=20\end{array}$ & $p$ & $\begin{array}{l}\text { Group B } \\
n=80\end{array}$ & $p$ \\
\hline Nicotine abuse (\%) & $22(22.0)$ & $24(24.0)$ & $0.876^{\mathrm{A}}$ & $6(30.0)$ & $0.562^{\mathrm{A}}$ & $18(22.5)$ & $1.000^{\mathrm{A}}$ \\
\hline Coronary heart disease/myocardial infarction $(\%)$ & $25(25.0)$ & $22(22.0)$ & $0.739^{\mathrm{A}}$ & $7(35.0)$ & $0.409^{\mathrm{A}}$ & $15(18.8)$ & $0.369^{\mathrm{A}}$ \\
\hline Atrial fibrillation (\%) & $52(52.0)$ & $39(39.0)$ & $0.088^{\mathrm{A}}$ & $10(50.0)$ & $1.000^{\mathrm{A}}$ & $29(36.3)$ & $0.037^{\mathrm{A}}$ \\
\hline Diabetes mellitus (\%) & $18(18.0)$ & $17(17.0)$ & $1.000^{\mathrm{A}}$ & $4(20.0)$ & $0.761^{\mathrm{A}}$ & $13(16.2)$ & $1.000^{\mathrm{A}}$ \\
\hline Heart failure $(\%)$ & $8(8.0)$ & $14(14.0)$ & $0.258^{\mathrm{A}}$ & $2(10.0)$ & $0.672^{\mathrm{A}}$ & $12(15.0)$ & $0.157^{\mathrm{A}}$ \\
\hline Hyperlipoproteinemia (\%) & $27(27.0)$ & $27(27.0)$ & $1.000^{\mathrm{A}}$ & $6(30.0)$ & $0.788^{\mathrm{A}}$ & $21(26.2)$ & $1.000^{\mathrm{A}}$ \\
\hline Hypertension (\%) & $74(74.0)$ & $72(72.0)$ & $0.874^{\mathrm{A}}$ & $16(80.0)$ & $0.778^{\mathrm{A}}$ & $56(70.0)$ & $0.616^{\mathrm{A}}$ \\
\hline Chronic kidney disease $(\%)$ & $8(8.0)$ & $8(8.0)$ & $1.000^{\mathrm{A}}$ & $2(10.0)$ & $0.672^{\mathrm{A}}$ & $7(8.8)$ & $1.000^{\mathrm{A}}$ \\
\hline Patent foramen ovale (\%) & $2(2.0)$ & $5(5.0)$ & $0.445^{\mathrm{A}}$ & $0(0.0)$ & $1.000^{\mathrm{A}}$ & $5(6.3)$ & $0.244^{\mathrm{A}}$ \\
\hline Endocarditis (\%) & $1(1.0)$ & $0(0.0)$ & $1.000^{\mathrm{A}}$ & $0(0.0)$ & $1.000^{\mathrm{A}}$ & $0(0.0)$ & $1.000^{\mathrm{A}}$ \\
\hline Peripheral arterial occlusive disease (\%) & $4(4.0)$ & $10(10.0)$ & $0.164^{\mathrm{A}}$ & $4(20.0)$ & $0.026^{\mathrm{A}}$ & $6(7.5)$ & $0.343^{\mathrm{A}}$ \\
\hline Autoimmune disease $^{\#}(\%)$ & $2(2.0)$ & $4(4.0)$ & $0.683^{\mathrm{A}}$ & $0(0.0)$ & $1.000^{\mathrm{A}}$ & $4(5.0)$ & $0.409^{\mathrm{A}}$ \\
\hline Tumors $^{+}(\%)$ & $6(6.0)$ & $7(7.0)$ & $1.000^{\mathrm{A}}$ & $1(5.0)$ & $1.000^{\mathrm{A}}$ & $6(7.5)$ & $0.768^{\mathrm{A}}$ \\
\hline Coagulation disorder $\sim(\%)$ & $1(1.0)$ & $6(6.0)$ & $0.118^{\mathrm{A}}$ & $0(0.0)$ & $1.000^{\mathrm{A}}$ & $6(7.5)$ & $0.046^{\mathrm{A}}$ \\
\hline Stroke/TIA in history $(\%)$ & $19(19.0)$ & $16(16.0)$ & $0.710^{\mathrm{A}}$ & $5(25.0)$ & $0.547^{\mathrm{A}}$ & $11(13.8)$ & $0.423^{\mathrm{A}}$ \\
\hline Thrombosis/lung embolism in history (\%) & $2(2.0)$ & $4(4.0)$ & $0.683^{\mathrm{A}}$ & $1(5.0)$ & $0.424^{\mathrm{A}}$ & $3(3.8)$ & $0.479^{\mathrm{A}}$ \\
\hline Low molecular weight heparin (\%) & $6(6.0)$ & $3(3.0)$ & $0.498^{\mathrm{A}}$ & $2(10.0)$ & $0.619^{\mathrm{A}}$ & $1(1.3)$ & $0.134^{\mathrm{A}}$ \\
\hline Unfractionated heparin (\%) & $3(3.0)$ & $1(1.0)$ & $0.621^{\mathrm{A}}$ & $0(0.0)$ & $1.000^{\mathrm{A}}$ & $1(1.3)$ & $0.630^{\mathrm{A}}$ \\
\hline Coumarins $(\%)$ & $10(10.0)$ & $9(9.0)$ & $1.000^{\mathrm{A}}$ & $1(5.0)$ & $0.689^{\mathrm{A}}$ & $8(10.0)$ & $1.000^{\mathrm{A}}$ \\
\hline New oral anticoagulants (\%) & $8(8.0)$ & $6(6.0)$ & $0.783^{\mathrm{A}}$ & $1(5.0)$ & $1.000^{\mathrm{A}}$ & $5(6.3)$ & $0.776^{\mathrm{A}}$ \\
\hline Dabigatran $(\%)$ & $2(2.0)$ & $0(0.0)$ & $0.497^{\mathrm{A}}$ & $0(0.0)$ & $1.000^{\mathrm{A}}$ & $0(0.0)$ & $0.503^{\mathrm{A}}$ \\
\hline Edoxaban $(\%)$ & $1(1.0)$ & $0(0.0)$ & $1.000^{\mathrm{A}}$ & $0(0.0)$ & $1.000^{\mathrm{A}}$ & $0(0.0)$ & $1.000^{\mathrm{A}}$ \\
\hline Apixaban $(\%)$ & $2(2.0)$ & $5(0.0)$ & $0.445^{\mathrm{A}}$ & $1(5.0)$ & $0.424^{\mathrm{A}}$ & $4(5.0)$ & $0.409^{\mathrm{A}}$ \\
\hline Rivaroxaban (\%) & $3(3.0)$ & $1(1.0)$ & $0.621^{\mathrm{A}}$ & $0(0.0)$ & $1.000^{\mathrm{A}}$ & $1(1.3)$ & $0.630^{\mathrm{A}}$ \\
\hline Ace-inhibitors (\%) & $30(30.0)$ & $27(27.0)$ & $0.754^{\mathrm{A}}$ & $8(40.0)$ & $0.435^{\mathrm{A}}$ & $19(23.8)$ & $0.401^{\mathrm{A}}$ \\
\hline AT1-receptor antagonists $8 \%$ ) & $23(23.0)$ & $19(19.0)$ & $0.603^{\mathrm{A}}$ & $4(20.0)$ & $1.000^{\mathrm{A}}$ & $15(18.8)$ & $0.582^{\mathrm{A}}$ \\
\hline Betablockers (\%) & $61(61.0)$ & $55(55.0)$ & $0.474^{\mathrm{A}}$ & $12(60.0)$ & $1.000^{\mathrm{A}}$ & $43(53.8)$ & $0.364^{\mathrm{A}}$ \\
\hline Diuretics $(\%)$ & $35(35.0)$ & $43(43.0)$ & $0.310^{\mathrm{A}}$ & $9(45.0)$ & $0.450^{\mathrm{A}}$ & $34(42.5)$ & $0.355^{\mathrm{A}}$ \\
\hline Calcium channel blockers (\%) & $27(27.0)$ & $19(19.0)$ & $0.239^{\mathrm{A}}$ & $3(15.0)$ & $0.397^{\mathrm{A}}$ & $16(20.0)$ & $0.296^{\mathrm{A}}$ \\
\hline Nitrates $(\%)$ & $8(8.0)$ & $1(1.0)$ & $0.035^{\mathrm{A}}$ & $1(5.0)$ & $1.000^{\mathrm{A}}$ & $0(0.0)$ & $0.009^{\mathrm{A}}$ \\
\hline Statins $(\%)$ & $31(31.0)$ & $30(30.0)$ & $1.000^{\mathrm{A}}$ & $10(50.0)$ & $0.124^{\mathrm{A}}$ & $20(25.0)$ & $0.409^{\mathrm{A}}$ \\
\hline Metamizole (\%) & $10(10.0)$ & $9(9.0)$ & $1.000^{\mathrm{A}}$ & $2(10.0)$ & $1.000^{\mathrm{A}}$ & $7(8.8)$ & $0.804^{\mathrm{A}}$ \\
\hline Ibuprofen $(\%)$ & $2(2.0)$ & $4(4.0)$ & $0.682^{\mathrm{A}}$ & $0(0.0)$ & $1.000^{\mathrm{A}}$ & $4(5.0)$ & $0.409^{\mathrm{A}}$ \\
\hline Acetylsalicylic acid (\%) & $21(21.0)$ & $31(31.0)$ & $0.146^{\mathrm{A}}$ & $9(45.0)$ & $0.044^{\mathrm{A}}$ & $22(27.5)$ & $0.380^{\mathrm{A}}$ \\
\hline Clopidogrel (\%) & $4(4.0)$ & $8(8.0)$ & $0.373^{\mathrm{A}}$ & $3(15.0)$ & $0.090^{\mathrm{A}}$ & $5(6.3)$ & $0.514^{\mathrm{A}}$ \\
\hline Thyroxine (\%) & $17(17.0)$ & $16(16.0)$ & $1.000^{\mathrm{A}}$ & $4(20.0)$ & $0.751^{\mathrm{A}}$ & $12(15.0)$ & $0.839^{\mathrm{A}}$ \\
\hline Glucocorticoids (\%) & $2(2.0)$ & $5(5.0)$ & $0.445^{\mathrm{A}}$ & $2(10.0)$ & $0.129^{\mathrm{A}}$ & $3(3.8)$ & $0.657^{\mathrm{A}}$ \\
\hline Lesion in internal carotid artery $(\%)$ & $40(40.0)$ & $42(42.0)$ & $0.886^{\mathrm{A}}$ & $13(65.0)$ & $0.050^{\mathrm{A}}$ & $29(36.3)$ & $0.646^{\mathrm{A}}$ \\
\hline Lesion in middle cerebral artery. M1 (\%) & $49(49.0)$ & $39(39.0)$ & $0.200^{\mathrm{A}}$ & $3(15.0)$ & $0.006^{\mathrm{A}}$ & $36(45.0)$ & $0.653^{\mathrm{A}}$ \\
\hline Lesion in middle cerebral artery M2 (\%) & $11(11.0)$ & $19(19.0)$ & $0.165^{\mathrm{A}}$ & $4(20.0)$ & $0.274^{\mathrm{A}}$ & $15(18.8)$ & $0.200^{\mathrm{A}}$ \\
\hline Right hemisphere (\%) & $43(43.0)$ & $39(39.0)$ & $0.666^{\mathrm{A}}$ & $11(55.0)$ & $0.338^{\mathrm{A}}$ & $28(35.0)$ & $0.287^{\mathrm{A}}$ \\
\hline Left hemisphere (\%) & $57(57.0)$ & $61(61.0)$ & $0.666^{\mathrm{A}}$ & $9(45.0)$ & $0.338^{\mathrm{A}}$ & $52(65.0)$ & $0.287^{\mathrm{A}}$ \\
\hline Initial NIH-Stroke-Scale (M and IQR) & $15(11-19)$ & $14(10-19)$ & $0.578^{\mathrm{B}}$ & $14(10-17)$ & $0.457^{\mathrm{A}}$ & $15(10-20)$ & $0.723^{\mathrm{B}}$ \\
\hline Intravenous thrombolysis (\%) & $51(51.0)$ & $35(35.0)$ & $0.032^{\mathrm{A}}$ & $7(35.0)$ & $0.226^{\mathrm{A}}$ & $28(35.0)$ & $0.035^{\mathrm{A}}$ \\
\hline $\begin{array}{l}\text { Thrombolysis-intervention time [min] (M and } \\
\text { IQR) }\end{array}$ & $90(41-151)$ & $118(47-161)$ & $0.351^{\mathrm{B}}$ & $139(79-228)$ & $0.142^{\mathrm{A}}$ & $102(46-152)$ & $0.652^{\mathrm{B}}$ \\
\hline Onset-needle time [min] (M and IQR) & $90(73-126)$ & $91(77-117)$ & $0.413^{\mathrm{B}}$ & $95(80-150)$ & $0.793^{\mathrm{B}}$ & $91(75-132)$ & $0.404^{\mathrm{B}}$ \\
\hline Onset-groin-puncture time [min] (M and IQR) & $158(125-198)$ & $189(134-261)$ & $0.608^{\mathrm{B}}$ & $271(151-333)$ & $0.155^{\mathrm{B}}$ & $200(140-270)$ & $0.973^{\mathrm{B}}$ \\
\hline
\end{tabular}


Table 3 (continued)

\begin{tabular}{|c|c|c|c|c|c|c|c|}
\hline & $\begin{array}{l}\text { Success } \\
n=100\end{array}$ & $\begin{array}{l}\text { Failure } \\
n=100\end{array}$ & $p$ & $\begin{array}{l}\text { Group A } \\
n=20\end{array}$ & $p$ & $\begin{array}{l}\text { Group B } \\
n=80\end{array}$ & $p$ \\
\hline $\begin{array}{l}\text { Onset-end-of-intervention Time [min] (M and } \\
\text { IQR) }\end{array}$ & $194(145-239)$ & $236(220-301)$ & $0.055^{\mathrm{B}}$ & $308(188-375)$ & $0.199^{\mathrm{B}}$ & $272(202-318)$ & $0.085^{\mathrm{B}}$ \\
\hline Intervention duration [min] (M and IQR) & $23(14-36)$ & $50(36-90)$ & $0.000^{\mathrm{B}}$ & $27.5(23-52)$ & $0.665^{\mathrm{B}}$ & $58(44-73)$ & $0.000^{\mathrm{B}}$ \\
\hline Stroke of unknown onset (\%) & $20(20)$ & $26(26)$ & $0.401^{\mathrm{A}}$ & $6(30.0)$ & $0.374^{\mathrm{A}}$ & $20(25.0)$ & $0.473^{\mathrm{A}}$ \\
\hline C-reactive protein $[\mathrm{mg} / \mathrm{l}]$ (M and IQR) & $4.5(1.9-14.6)$ & $5.3(2.4-15.4)$ & $0.342^{\mathrm{B}}$ & $6.1(1.7-24.1)$ & $0.420^{\mathrm{B}}$ & $5.1(2.5-12.1)$ & $0.431^{\mathrm{B}}$ \\
\hline White blood cell count $\left[\times 10^{9} / 1\right](\bar{X} \pm \mathrm{SD})$ & $10.6 \pm 4.2$ & $10.4 \pm 5.3$ & $0.284^{\mathrm{B}}$ & $10.1 \pm 4.3$ & $0.576^{\mathrm{B}}$ & $9.2 \pm 3.9$ & $0.303^{\mathrm{B}}$ \\
\hline INR (M and IQR) & $\begin{array}{l}1.06 \\
(0.99-1.14)\end{array}$ & $\begin{array}{l}1.04 \\
(0.97-1.10)\end{array}$ & $0.276^{\mathrm{B}}$ & $\begin{array}{l}1.06 \\
(1.01-1.11)\end{array}$ & $0.719^{\mathrm{B}}$ & $\begin{array}{l}1.03 \\
(0.97-1.10)\end{array}$ & $0.153^{\mathrm{B}}$ \\
\hline aPTT [s] (M and IQR) & $24(23-27)$ & $24(22-27)$ & $0.639^{\mathrm{B}}$ & $25(22-28)$ & $0.899^{\mathrm{B}}$ & $24(23-27)$ & $0.546^{\mathrm{B}}$ \\
\hline Platelet count $\left[\times 10^{9} / 1\right](\mathrm{M}$ and IQR) & $228(186-274)$ & $223(160-277)$ & $0.258^{\mathrm{B}}$ & $199(142-276)$ & $0.108^{\mathrm{B}}$ & $227(170-277)$ & $0.500^{\mathrm{B}}$ \\
\hline
\end{tabular}

$A$, Fisher's exact test; $B$, Mann-Whitney $U$ test; $M$, median, $I Q R$, interquartile range; $\bar{X}$, mean; $S D$, standard deviation

\# Vasculitis, Hashimoto thyroiditis, Crohn's disease, rheumatoid arthritis, myasthenia gravis. No significant difference in any of the subcategories

+ Active tumor disease: small cell lung cancer, non-small cell lung cancer, colorectal carcinoma, mammary carcinoma, non-Hodgkin's lymphoma, chronic lymphocytic leukemia, plasmocytoma, malignant melanoma, thyroid cancer, transitional cell carcinoma of the urinary tract, oropharyngeal squamous cell carcinoma, meningeoma, prostate cancer, cancer of unknown primary. No significant difference in any of the subcategories

Heterozygous and homozygous G20210A-mutation, antiphospholipid syndrome, factor V Leiden mutation, protein c/s-deficiency, thrombotic thrombocytopenic purpura, paraneoplastic coagulation disorder. No significant difference in any of the subcategories

Compared to the successful group, in group A (A) there is a strong association between failing intervention and PAOD ( $\mathrm{SG}=4.0 \%$ vs. $A=20.0 \% ; p=0.026)$ as well as the intake of acetylsalicylic acid ( $\mathrm{SG}=21.0 \%$ vs. $A=45.0 \% ; p=$ $0.044)$. In group $A$, lesions are significantly more often located in the internal carotid artery ( $\mathrm{SG}=40.0 \%$ vs. $A=65.0 \%$; $p=0.050)$ and more rarely in the middle cerebral artery, segment $\mathrm{M} 1$ ( $\mathrm{SG}=49.0 \%$ vs. $A=15.0 \% ; p=0.006)$.

In group $\mathrm{B}(B)$, atrial fibrillation $(\mathrm{AF})$ is associated with recanalization success $(\mathrm{SG}=52.0 \%$ vs. $B=36.3 \%$; $p=$ 0.037), whereas coagulation disorders are associated with poor results ( $\mathrm{SG}=1.0 \%$ vs. $B=7.5 \% ; p=0.046$ ). Coagulation disorders particularly were defined as heterozygous (1 patient in B) and homozygous G20210A mutation ( 0 patients), antiphospholipid syndrome (2 patients, 1 in SG and 1 in B), factor V Leiden mutation (2 patients in B), protein $\mathrm{c} / \mathrm{s}$ deficiency (1 patient in B), thrombotic thrombocytopenic purpura (0 patients), or paraneoplastic coagulation disorder (1 patient in B).

\section{Discussion}

Several retrospective investigations concerning failing thrombectomy were published in recent months $[13,14]$. In our study, we were able to detect success rates of $83.2 \%$ at our center. We analyzed interventions from 2014 to 2018. In this period, major improvements of material and methods were made [15]. We found a peak of failing interventions in the year 2015 with many recanalization results of mTICI $2 \mathrm{a}$. When having a second look at the angiographic reports, no reason therefore could be found, especially no discrepancies in material or interventionalist. In 2014 and from 2016 to 2018 , the success rate at our center is in the range of 83 $86 \%$. Recent literature comes to similar success rates of around $80-89 \%[6,16]$, while older reviews indicate success rates of $80 \%$ [17].

A major problem when comparing different studies is the heterogeneous definition of success. In particular, a reperfusion result of mTICI $2 \mathrm{a}$ is sometimes regarded as success, sometimes as failure $[6,13,14,18,19]$.

In $20 \%$ of the failing interventions, the thrombus could not be reached or passed with the device while in $80 \%$ recanalization failed due to other reasons. Literature reports similar data [13]. For patients failing due to mechanical reasons, direct carotid puncture or surgical vascular access, which is currently not performed at our center, could be a therapeutic option in certain cases. Direct carotid puncture is a high-risk procedure, but recent literature reports successful recanalization in 8/11 reported cases, where a femoral approach had failed [20]. Further options for access problems, e.g., neck extension to stretch tortuous or elongated vessels should be investigated in upcoming studies [21].

In addition to procedural aspects, we analyzed patients' medical history. IVT is associated with improved recanalization rates. This can be explained by the pharmacologic mechanism: the clot is dissolved from the outer edge and can therefore be accessed by the mechanical device easier [22]. Another explanation could be, that small fragments of the initial thrombus are dissolved during the intervention and do not occlude distal branches. Several other studies come to similar findings when comparing patients with and without 
IVT for recanalization success, as shown in a recent review by Pan et al. [23]. It was to be expected that vascular diseases such as PAOD influence MT in a negative way. Coagulation disorders also are a challenge for interventional treatment, especially because of a high rate of re-occlusion during the intervention. We were able to prove a significant correlation between PAOD and failing intervention, as well as between coagulation disorders and unsuccessful thrombectomy.

In the group of patients where thrombus could be reached but the vessel remained occluded, AF is significantly less frequent. Recent literature also shows inconclusive findings concerning this aspect [24]. There are studies and histological analysis that come to a similar result $[25,26]$, while other investigations indicate the opposite: cardiogenic thrombi seem to have a higher proportion of fibrin compared to other stroke etiologies, associated with worse interventional recanalization rates [27-29]. More studies on thrombus etiology and thrombus composition must be performed.

It is not clear why there is a strong association of intake of $\mathrm{NO}$ donors and reperfusion success. Recent studies investigated NO donors as symptomatic treatment for acute ischemic stroke, but not as a medication to improve recanalization success [30]. Further studies are required to find out whether the result is an artifact or not.

There was no difference in any kind of anticoagulation therapy with coumarins, NOAC, or heparins regarding recanalization success. This is of special interest since many future patients will take NOACs instead of coumarins and we do not know the effects of NOACs on thrombus characteristics.

In the subgroup of failing interventions, where target lesion could be reached with the device, techniques should be improved, and new material should be developed. For example, recent studies suggest a proximal balloon occlusion during stent retriever withdrawal to protect the distal vessel from thrombus fragments that have sheared off [31]. As a rescue therapy, permanent stenting or intraarterial thrombolysis as well as administration of tirofiban are options worth considering [32-34]. In certain cases, creativity on the part of the interventionalist can lead to success: there are case reports of dual-use of stent retrievers for refractory clots involving vessels' bifurcation [35]. In general, more evidence for the question of how to treat patients with failing thrombectomy is required.

Since all patients in both groups were under general anesthesia during the intervention and we investigated the recanalization itself, we did not analyze anesthesiologic medication or blood pressure during the intervention. In literature, there is evidence for anesthesiologic management influencing outcome, but not recanalization results [36-39].

\section{Limitation}

It should be noted that only angiographic data and no clinical parameters concerning patient outcome were collected.
Nevertheless, there is a strong correlation between successful reperfusion and patients' outcome, as shown in recent literature [9, $10,19,40]$. The study cohort is the same size as in other comparable studies. Another limitation is the retrospective study design.

\section{Conclusion}

There are two main reasons for failing MT:

Major problems of failing thrombectomy, on the one hand, include a difficult vascular situation affecting interventional treatment in $20 \%$ of all failing interventions. The target lesion cannot be reached and/or passed with the device. Especially in those patients, PAOD is a common previous disease.

In the other $80 \%$ of all failing interventions, thrombus can be passed with the device, but the occluded vessel cannot be recanalized. Coagulation disorders are associated with poor results, whereas atrial fibrillation, intake of NO donators, and administration of intravenous thrombolysis are associated with higher recanalization rates.

Future research on improving recanalization rates should concentrate on the two key areas of access problems and true stent retriever failure.

Acknowledgements Open Access funding provided by Projekt DEAL.

Authorship contributions Dominik M. Heider (conceptualization, data collection, analysis and interpretation, manuscript draft writing)

Andreas Simgen (data collection, interpretation, manuscript review writing/editing)

Gudrun Wagenpfeil (statistical analysis)

Philipp Dietrich (resources)

Umut Yilmaz (resources, supervision)

Ruben Mühl-Benninghaus (resources)

Safwan Roumia (resources).

Klaus Fassbender (resources, supervision).

Wolfgang Reith (project development, resources, supervision)

Michael Kettner (conceptualization, data collection and interpretation, manuscript review writing/editing)

\section{Compliance with ethical standards}

Conflict of interest The authors declare that they have no conflicts of interest.

Ethical approval All procedures performed in studies involving human participants were in accordance with the ethical standards of the institutional and/or national research committee (Ethikkommission der Ärztekammer des Saarlandes, Reference BU126/19) and with the 1964 Helsinki declaration and its later amendments or comparable ethical standards. Patients' informed consent was not required due to the retrospective study design. This article does not contain any studies with animals performed by any of the authors.

Open Access This article is licensed under a Creative Commons Attribution 4.0 International License, which permits use, sharing, adaptation, distribution and reproduction in any medium or format, as long as you give appropriate credit to the original author(s) and the source, provide a link to the Creative Commons licence, and indicate if changes were 
made. The images or other third party material in this article are included in the article's Creative Commons licence, unless indicated otherwise in a credit line to the material. If material is not included in the article's Creative Commons licence and your intended use is not permitted by statutory regulation or exceeds the permitted use, you will need to obtain permission directly from the copyright holder. To view a copy of this licence, visit http://creativecommons.org/licenses/by/4.0/.

\section{References}

1. Berkhemer OA, Fransen PS, Beumer D, van den Berg L, Lingsma HF, Yoo AJ, Schonewille WJ, Vos JA, Nederkoorn PJ, Wermer MJ, van Walderveen M, Staals J, Hofmeijer J, van Oostayen J, Lycklama à Nijeholt GJ, Boiten J, Brouwer PA, Emmer BJ, de Bruijn SF, van Dijk L, Kappelle LJ, Lo RH, van Dijk E, de Vries J, de Kort PL, van Rooij W, van den Berg J, van Hasselt B, Aerden LA, Dallinga RJ, Visser MC, Bot JC, Vroomen PC, Eshghi O, Schreuder TH, Heijboer RJ, Keizer K, Tielbeek AV, den Hertog H, Gerrits DG, van den Berg-Vos R, Karas GB, Steyerberg EW, Flach HZ, Marquering HA, Sprengers ME, Jenniskens SF, Beenen LF, van den Berg R, Koudstaal PJ, van Zwam W, Roos YB, van der Lugt A, van Oostenbrugge R, Majoie CB, Dippel DW, MR CLEAN Investigators (2015) A randomized trial of intraarterial treatment for acute ischemic stroke. N Engl J Med 372(1):11-20

2. Campbell BC et al (2015) Endovascular therapy for ischemic stroke with perfusion-imaging selection. N Engl J Med 372(11):10091018

3. Goyal M, Demchuk AM, Menon BK, Eesa M, Rempel JL, Thornton J, Roy D, Jovin TG, Willinsky RA, Sapkota BL, Dowlatshahi D, Frei DF, Kamal NR, Montanera WJ, Poppe AY, Ryckborst KJ, Silver FL, Shuaib A, Tampieri D, Williams D, Bang OY, Baxter BW, Burns PA, Choe H, Heo JH, Holmstedt CA, Jankowitz B, Kelly M, Linares G, Mandzia JL, Shankar J, Sohn SI, Swartz RH, Barber PA, Coutts SB, Smith EE, Morrish WF, Weill A, Subramaniam S, Mitha AP, Wong JH, Lowerison MW, Sajobi TT, Hill MD, ESCAPE Trial Investigators (2015) Randomized assessment of rapid endovascular treatment of ischemic stroke. N Engl J Med 372(11):1019-1030

4. Jovin TG, Chamorro A, Cobo E, de Miquel MA, Molina CA, Rovira A, San Román L, Serena J, Abilleira S, Ribó M, Millán M, Urra X, Cardona P, López-Cancio E, Tomasello A, Castaño C, Blasco J, Aja L, Dorado L, Quesada H, Rubiera M, HernandezPérez M, Goyal M, Demchuk AM, von Kummer R, Gallofré M, Dávalos A, REVASCAT Trial Investigators (2015) Thrombectomy within 8 hours after symptom onset in ischemic stroke. N Engl J Med 372(24):2296-2306

5. Saver JL, Goyal M, Bonafe A, Diener HC, Levy EI, Pereira VM, Albers GW, Cognard C, Cohen DJ, Hacke W, Jansen O, Jovin TG, Mattle HP, Nogueira RG, Siddiqui AH, Yavagal DR, Baxter BW, Devlin TG, Lopes DK, Reddy VK, du Mesnil de Rochemont R, Singer OC, Jahan R, SWIFT PRIME Investigators (2015) Stentretriever thrombectomy after intravenous t-PA vs. t-PA alone in stroke. N Engl J Med 372(24):2285-2295

6. Tsang COA, Cheung IHW, Lau KK, Brinjikji W, Kallmes DF, Krings T (2018) Outcomes of stent retriever versus aspiration-first Thrombectomy in ischemic stroke: a systematic review and metaanalysis. Am J Neuroradiol 39:2070-2076

7. Kim BM (2017) Causes and solutions of endovascular treatment failure. J Stroke 19(2):131-142

8. Yeo LLL, Bhogal P, Gopinathan A, Cunli Y, Tan B, Andersson T (2019) Why does mechanical thrombectomy in large vessel occlusion sometimes fail? Clin Neuroradiol 29:401-414
9. Ribo M et al (2013) Difficult catheter access to the occluded vessel during endovascular treatment of acute ischemic stroke is associated with worse clinical outcome. J Neurointerv Surg 5(Suppl 1):i70 i73

10. Chamorro Á et al (2017) Complete reperfusion is required for maximal benefits of mechanical thrombectomy in stroke patients. Sci Rep 7(1):11636

11. Zaidat $\mathrm{OO}$ et al (2013) Recommendations on angiographic revascularization grading standards for acute ischemic stroke: a consensus statement. Stroke 44(9):2650-2663

12. Brott $\mathrm{T}$ et al (1989) Measurements of acute cerebral infarction: a clinical examination scale. Stroke 20(7):864-870

13. Leischner H, Flottmann F, Hanning U, Broocks G, Faizy TD, DebChatterji M, Bernhardt M, Brekenfeld C, Buhk JH, Gellissen S, Thomalla G, Gerloff C, Fiehler J (2019) Reasons for failed endovascular recanalization attempts in stroke patients. $\mathrm{J}$ NeuroInterv Surg 11(5):439-442

14. Kaesmacher J, Gralla J, Mosimann PJ, Zibold F, Heldner MR, Piechowiak E, Dobrocky T, Arnold M, Fischer U, Mordasini P (2018) Reasons for reperfusion failures in stent-retriever-based thrombectomy: registry analysis and proposal of a classification system. AJNR Am J Neuroradiol 39(10):1848-1853

15. Bhaskar S, Stanwell P, Cordato D, Attia J, Levi C (2018) Reperfusion therapy in acute ischemic stroke: dawn of a new era? BMC Neurol 18(1):8

16. Primiani CT, Vicente AC, Brannick MT, Turk AS, Mocco J, Levy EI, Siddiqui AH, Mokin M (2019) Direct aspiration versus stent retriever thrombectomy for acute stroke: a systematic review and meta-analysis in 9127 patients. J Stroke Cerebrovasc Dis 28(5): 1329-1337

17. Puñal-Riobóo J, Atienza G, Blanco M (2015) Safety and efficacy of mechanical thrombectomy using stent retrievers in the endovascular treatment of acute ischaemic stroke: a systematic review. Interv Neurol 3(3-4):149-164

18. Kleine JF et al (2016) Time to redefine success? TICI 3 versus TICI $2 \mathrm{~b}$ recanalization in middle cerebral artery occlusion treated with thrombectomy. J Neurointerv Surg. 2017 Feb;9(2):117-121

19. Naragum V, Jindal G, Miller T, Kole M, Shivashankar R, Merino JG, Cole J, Chen R, Kohler N, Gandhi D (2018) Functional Independence after stroke thrombectomy using thrombolysis in cerebral infarction grade $2 \mathrm{c}$ : a new aim of successful revascularization. World Neurosurg 119:e928-e933

20. Roche A, Griffin E, Looby S, Brennan P, O'Hare A, Thornton J, Boyle K, Williams D, Moynihan B, Power S (2019) Direct carotid puncture for endovascular thrombectomy in acute ischemic stroke. J Neurointerv Surg 11:647-652

21. Kim SU et al (2019) Feasibility of using neck extension to overcome a difficult aortic arch and gain access to the carotid artery. World Neurosurg. 2019 May;125:e110-e116.

22. Maingard J et al (2019) Outcomes of endovascular thrombectomy with and without bridging thrombolysis for acute large vessel occlusion ischaemic stroke. Intern Med J 49(3):345-351

23. Pan X, Liu G, Wu B, Liu X, Fang Y (2019) Comparative efficacy and safety of bridging strategies with direct mechanical thrombectomy in large vessel occlusion: a systematic review and meta-analysis. Medicine (Baltimore) 98(14):e14956

24. Bacigaluppi $\mathrm{M}$ et al (2019) Insights from thrombi retrieved in stroke due to large vessel occlusion. J Cereb Blood Flow Metab. 2019 Aug;39(8):1433-1451.

25. Mascitelli JR, Kellner CP, Oravec CS, de Leacy RA, Oermann EK, Yaeger K, Paramasivam S, Fifi JT, Mocco J (2017) Factors associated with successful revascularization using the aspiration component of ADAPT in the treatment of acute ischemic stroke. J NeuroInterv Surg 9(7):636-640

26. Kim SK, Yoon W, Kim TS, Kim HS, Heo TW, Park MS (2015) Histologic analysis of retrieved clots in acute ischemic stroke: 
correlation with stroke etiology and gradient-Echo MRI. AJNR Am J Neuroradiol 36(9):1756-1762

27. Maekawa K et al (2018) Erythrocyte-rich thrombus is associated with reduced number of maneuvers and procedure time in patients with acute ischemic stroke undergoing mechanical thrombectomy. Cerebrovasc Dis Extra 8(1):39-49

28. Ahn SH, Hong R, Choo IS, Heo JH, Nam HS, Kang HG, Kim HW, Kim JH (2016) Histologic features of acute thrombi retrieved from stroke patients during mechanical reperfusion therapy. Int J Stroke 11(9):1036-1044

29. Sporns PB, Hanning U, Schwindt W, Velasco A, Buerke B, Cnyrim C, Minnerup J, Heindel W, Jeibmann A, Niederstadt T (2017) Ischemic stroke: histological thrombus composition and preinterventional $\mathrm{CT}$ attenuation are associated with intervention time and rate of secondary embolism. Cerebrovasc Dis 44(5-6):344-350

30. Bath PM, Krishnan K, Appleton JP (2017) Nitric oxide donors (nitrates), L-arginine, or nitric oxide synthase inhibitors for acute stroke. Cochrane Database Syst Rev 4:Cd000398

31. Maegerlein C, Mönch S, Boeckh-Behrens T, Lehm M, Hedderich DM, Berndt MT, Wunderlich S, Zimmer C, Kaesmacher J, Friedrich B (2018) PROTECT: PRoximal balloon occlusion together with direct thrombus aspiration during stent retriever thrombectomy - evaluation of a double embolic protection approach in endovascular stroke treatment. J Neurointerv Surg 10(8):751-755

32. Anadani M, Ajinkya S, Alawieh A, Vargas J, Chatterjee A, Turk A, Spiotta AM (2019) Intra-arterial tissue plasminogen activator is a safe rescue therapy with mechanical thrombectomy. World Neurosurg 123:e604-e608

33. Chang Y, Kim BM, Bang OY, Baek JH, Heo JH, Nam HS, Kim YD, Yoo J, Kim DJ, Jeon P, Baik SK, Suh SH, Lee KY, Kwak HS, Roh HG, Lee YJ, Kim SH, Ryu CW, Ihn YK, Kim B, Jeon HJ, Kim JW, Byun JS, Suh S, Park JJ, Lee WJ, Roh J, Shin BS, Kim JM (2018) Rescue stenting for failed mechanical thrombectomy in acute ischemic stroke: a multicenter experience. Stroke 49(4): 958-964
34. Zhang S et al (2019) Safety of intra-arterial tirofiban administration in ischemic stroke patients after unsuccessful mechanical thrombectomy. J Vasc Interv Radiol 30(2):141-147.e1

35. Patro SN, Iancu D (2017) Dual-stent retrieval for mechanical thrombectomy of refractory clot in acute stroke as a rescue technique. Cmaj 189(17):E634-e637

36. Ilyas A, Chen CJ, Ding D, Foreman PM, Buell TJ, Ironside N, Taylor DG, Kalani MY, Park MS, Southerland AM, Worrall BB (2018) Endovascular mechanical thrombectomy for acute ischemic stroke under general anesthesia versus conscious sedation: a systematic review and meta-analysis. World Neurosurg 112:e355e367

37. Eker OF et al (2018) Impact of anesthetic management on safety and outcomes following mechanical thrombectomy for ischemic stroke in SWIFT PRIME cohort. Front Neurol 9:702

38. Abou-Chebl A, Zaidat OO, Castonguay AC, Gupta R, Sun CH, Martin CO, Holloway WE, Mueller-Kronast N, English JD, Linfante I, Dabus G, Malisch TW, Marden FA, Bozorgchami H, Xavier A, Rai AT, Froehler MT, Badruddin A, Nguyen TN, Taqi M, Abraham MG, Janardhan V, Shaltoni H, Novakovic R, Yoo AJ, Chen PR, Britz GW, Kaushal R, Nanda A, Issa MA, Nogueira RG (2014) North American SOLITAIRE stent-retriever acute stroke registry: choice of anesthesia and outcomes. Stroke 45(5): 1396-1401

39. Lowhagen Henden P et al (2017) General anesthesia versus conscious sedation for endovascular treatment of acute ischemic stroke: the AnStroke trial (anesthesia during stroke). Stroke 48(6):16011607

40. Dekker L, Geraedts VJ, Hund H, Cannegieter SC, Nogueira RG, Goyal M, van den Wijngaard I (2018) Importance of reperfusion status after intra-arterial thrombectomy for prediction of outcome in anterior circulation large vessel stroke. Interv Neurol 7(3-4):137147

Publisher's note Springer Nature remains neutral with regard to jurisdictional claims in published maps and institutional affiliations. 